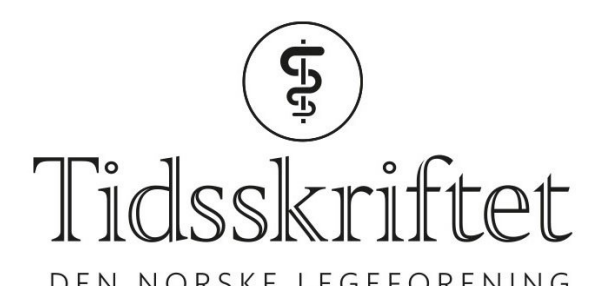

DEN NORSKE LEGEFORENING

\title{
Jana Rydland
}

MINNEORD

ÅSE KJELLMO

MARI FOLVIK

GUNNAR MYHR

ASBJØRN ØDEGÅRD

KJELL ARNE KVISTAD

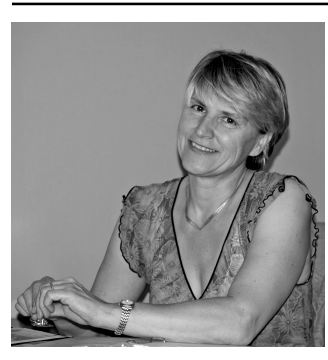

Jana Rydland døde brått 1. juni 2017, bare 59 år gammel. Jana var født og oppvokst i Praha i en fargerik familie av leger, advokater og operasangere. Hun utdannet seg til tannlege i hjembyen, men på slutten av studiet traff hun Terje fra Trondheim. Det var den store kjærligheten - som førte til giftermål, nytt land og ny hjemby. Hun var full av pågangsmot, ny kultur og nytt språk var ikke tilstrekkelig utfordring, nytt yrkesvalg ble det også. Hun gikk i gang med medisinstudiet ved Norges teknisk-naturvitenskapelige universitet og utmerket seg som en glimrende student.

Jana var svært sosial, lærte seg norsk raskt og fikk studievenner som hun beholdt hele livet. Etter turnus, en periode i allmennpraksis og to barnefødsler begynte hun i 1991 på spesialistutdanning i radiologi ved Regionsykehuset i Trondheim. Etter fullført spesialitet gikk veien videre til MR-senteret og fordyping i MR-radiologi. Etter dette har arbeidsplassen vært Nevroseksjonen ved Klinikk for bildediagnostikk, St. Olavs hospital.

Det var ingen tilfeldighet at hun valgte radiologi, hennes mor var barneradiolog og en eldre bror nevroradiolog. Nevroradiologi med spesielt ansvar for barnenevroradiologi ble Janas fagfelt, et område hun behersket til fingerspissene. Hun hadde en altoppslukende kunnskapstørst og var svært samvittighetsfull - hun nøyde seg ikke med å granske bildene, hele pasienten var hennes ansvar. Alle steiner ble snudd i letingen etter rett diagnose og behandling. 
Jakten på kunnskap førte Jana til en rekke internasjonale kurs og kongresser. Med sitt pågangsmot og sine gode sosiale evner fikk hun raskt et stort kontaktnett av de fremste ekspertene i verden innen hennes fagfelt. Dette samarbeidet ble viktig, særlig for barn med sjeldne sykdommer i sentralnervesystemet, som Jana sørget for fikk diagnostikk på aller høyeste nivå. Hun var aktiv i den nasjonale faggruppen for CNS-svulster hos barn og møtte alltid godt forberedt, med presentasjoner av lærerike kasuistikker og grundig innsatt i litteraturen. Hun hadde stor arbeidskapasitet, i tillegg til lange dager på sykehuset arbeidet hun mange år som fagkonsulent for MR-diagnostikk i Capio Røntgen Trondheim i fritiden.

Som kollega var hun snill og uselvisk, den som aldri fremhevet seg selv og som gjerne tok de upopulære vaktene i jul og påske. Privat var hun en omsorgsfull mor og navet i vennenes sosiale liv. Hun briljerte som arrangør av venneturer til en rekke byer, ikke minst Praha, som hun var svært knyttet til og dit hun planla å flytte tilbake til som pensjonist.

Jana vil bli dypt savnet av sine venner på Klinikk for bildediagnostikk og av klinikerne på sykehuset. Vi har mistet en kjær venn og en dedikert og utrolig kunnskapsrik kollega. Våre tanker går til hennes mann Terje og barna Eva og Martin.

På vegne av venner og kolleger

Publisert: 30. oktober 2017. Tidsskr Nor Legeforen. DOI: 10.4045/tidsskr.17.0799

(C) Tidsskrift for Den norske legeforening 2020. Lastet ned fra tidsskriftet.no 